\title{
Enhancing Intercultural and Interlingual Communication of EFL Learners' Ability Through English Literature
}

\author{
Kurnia Ningsih \\ FBS UNP \\ Padang \\ krn_ningsih@yahoo.com
}

\begin{abstract}
This article emphasizes the fundamental role of English Literature in enhancing intercultural and interlingual communication of EFL learners'ability. Language and culture are bound together which can not be separated when people interact and communicate each other. Language is vital factor in interaction especially in globalization era where people from different country and culture communicate each other. Thus learning language means learning cuture. Besides, curriculumn 2013 for Indonesian's school requires the teacher to develop the learners'ability in using Engish for International communication. However it can be troublesome for EFL learners who have no prior experience of culture learning in foreign language classroom. They tend to consider intercultural and interlingual communication just simply use English conversation without paying attention to cultural differences. The best material that can help teachers to develop the learners' ability is English Literature. It is authentic material and full of language used in different social-context that can not be found in the text book. The material provides the components of language that can be applied in four skills. Furthermore the literary works reflect the daily life of people in particular culture. Through literary works indirectly they are able to enhance their knowledge about society in a certain culture as well as to develop their own characters. Thus this article is going to discuss in what way English literature help the teachers and the learners develop their ability in intercultural and interlingual communication
\end{abstract}

Keywords-Intercultural and Interlingual

Communication, learner's ability and Literature

\section{INTRODUCTION}

Global era has made the world smaller day by day. With the sophisticated technology, faster and easier transportation interraction and communication with the people across the world are opened wildly. Internet especially has triggered and offered the chance for people around the world to build relationship. Besides, many opportunity are available especially for students to communicate with others from different countries by using English as a shared language. Many countries also increase the exchange programs among schools, universities even youth itself. Indonesia is one of them. Thus the number of people who speak more than one language grows rapidly. Language certainly is a vital factor in interaction which can not be separated from the culture in which it belongs to.
Language and culture are bound together when people interract and communicate each other. The curriculumn 2013 for school in Indonesia requires the teachers to develop the learners'ability in using Engish for International communication. This is the good point since Indonesia consists of many tribes with different language and culture that trigger people to know and come to a visit.

Using language means using culture indirectly. Unfortunately not many people are aware of using language in such a way. EFL students in Asia countries tend to consider intercultural communication similar to general communication in which one simply has an English conversation with others without paying attention to cultural differences [1]. In fact any languages can not be used by ignoring the context and function based on its own culture. Communication is becoming more and more intercultural because it involves interlocutors who have different first languages, communicate in a common language and represent different cultures [2]. This aspect should be considered by the teachers in teaching language so that they can provide their students with the knowledge as well as the skills of using language during the interraction in intercultural and interligual communication. Thus one of the crucial points that can support the teaching learning in the class is the teaching materials. The teachers should rely on authentic material. Comparing to English textbook, Authentic material is more flexible and consists of the language used in daily life so that it can be used as a model how people interract and communicate based on the context and function in reality. This paper discusses that English literary works used as an authentic material for teachinglearning is able to enhance the ability of the EFL's learners in interlcultural and interlingual communication.

\section{INTERCULTURAL AND INTERLINGUAL COMMUNICATION}

As members of society, people can not avoid to communicate each other since interaction is as a sign of their existence as well as to establish their social relationship by which they share information, ideas even their feeling. The interaction do not only occur among the members, they even can communicate with others from different society and culture. Language surely becomes a power tool in communication. Each language is unique 
since it grows in a certain culture. Language designed and structured by pattern of culture acts as communication tool [3]. It carries and transmits social/ cultural traits through generation. Thus if people use language they can't ignore the social function and purpose which is certainly based on the cultural context. Since globalization has made them have more than one language, they are indirectly involved in intercultural and interlingual communication. English especially has been used as an international language where people from different culture communicate with it. The conceptual of intercultural communication as a transactional, symbolic process involving the attribution of meaning between people from different cultures [4]. He adds that the keyword here is a process. Thus intercultural communication should be viewed and analyzed as a complex process, not merely as an encounter. Therefore providing optimal intercultural competence is essential in order to help them manage the interaction.

The learners of EFL should be taught intercultural competence so that they are aware that language is not just words, grammar and pronounciation, but it also consists of communication components. There are four components of communication. First, the goal of communication such as: to give or to get information, to offer ideas, to express opinions, to change minds, to change other people's behavior even to creat the mood. Second, consideration for other which means ability to know the need, expectation and motives of the listener. Third, how communication operates, it should be understood that Communication is dynamic, and flexible process so that people have to be alert and adaptable and considerate. Fourth, effective performance which deals with how to organize and present the information or ideas. Besides, people need to have skills in communication. It is important to take into account that interaction involves two speakers who can understand each other [3].

The learner's of EFL should be trained to recognize that language is bound to its culture. Some points to be considered by the teachers in teaching-learning process: (1) integrate the knowledge of language with the components of culture. Show the learner the differences and the similarity of the language they learn to theirs. (2) the teaching should not focus on verbal language only but also non verbal that could affect the miscommunication. (3) the teachers should understand that the aims of teaching is to enable learners to adjust their attitude as well as develop intercultural communication competence [1]. These consideration is going to affect the choosing of the materials given to the learners. Building the competence is not enough by providing students with knowledge and skills only, however the students should get the experience of using the language they learn in order to enhance their ability in intercultural and interlingual communication.

\section{Why USING ENGLISH LITERATURE}

To build the ability of the EFL students in intercultural and interlingual interaction, there are many factors should be considered by the teachers in teachinglearning such as materials and strategy. Bravo (2006) quoted by Aghagolzadeh and Tajabadi states that one of the main reason for using authentic material in the classroom is the learner will not encounter the artificial language of classroom but the real world and language how it is really used [5]. The teachers to adopt authentic teaching materials to strengthen EFL students' knowledge of different cultures [1]. Authentic material offers the chance for them to learn cultural differences across the world. He then adds that the teaching content should include knowledge of communicative strategies. Literature as aesthetics creation is rich source of authentic material since it conveys language in use and represent the spoken and written language within a certain cultural context [6]. One of the authentic materials that can be brought into the classroom and fulfill the need of intercultural communication is English literature text. The text does not mean only from British literature. Many authors nowadays use English in writing their work since they have been grown up in English country. Some stories has already translated into English by pople who are good in Literature as well as English. It is interesting since all the stories come from different countries around the world, including Indonesia. This implicitly represent the culture of the society. Besides, the literary text has difference genre that are available to be taken into account. It is just a tool that is able to help students to encounter what they really need in reality.

Furthermore, Literature text are rich with sociolinguitic aspects [7]. The text provides students with a wide range of language varieties like sociolects, regional dialect, jargon, idiolects etc. A character speaks differently in different social context like, school, hospital, family, among friends, police station etc. They even present formal, informal, casual, frozen and close styles speech. He then suggests that literature text can be used for teaching both basic language skills and language components that usefull for EFL learners. Collie and Slater quoted by Rai (71) state that there are four main reasons why the teachers are persuaded to use English literature text. (1) Valuable authentic material since they expose the learners to actual language samples of real life. (2) Cultural Enrichment. Literary works such as novels, plays, short stories and poetry facilitate understanding how communication takes place in the society of the country. Though the text are just imaginative writing but they present full and colourful setting in which characters from different social background can be described.(3) Language Enrichment. The texts are rich of naturalness of language use that can provide students with wide range of syntactic items, discource functions of sentence, different ways of connecting ideas that they need for the skills of language. (4) Personal Involvement. Once they involve in literary text they feel excited to find out what happens, they even feel close to a certain character and share the emotional response. This can have beneficial effects to the whole language learning process which is good for them. Thus if the goal of teaching Engish is to 
encourage students to use language for international communication, literature text is the valuable material that can help teachers and students in facing new language. The teachers are even able to create the interesting integrated activities that make students eager to study.

\section{ENHANCING INTERCULTURAL AND INTERLINGUAL \\ COMMUNICATION IN TEACHING AND LEARNING EFL}

The aim of teaching English as Foreign Language is to help learners aquire communicative competence so that they can have interaction in English as a shared language. Therefore the teachers are required seriusly to consider teaching materials that can be applied in the classroom. Life and interaction with the world shapes our thoughts and language [2]. What people of a language community find important to be expressed in their life will definitely be expressed in that language. Therefore it is suggested to use the literary works such as prose (short storey, novel), drama and poetry for teaching in the classroom.. It is not necessary to take the whole works, the teacher may use part of the work that is really interesting to be applied in teachinglearning EFL. The advantage of the materials is Literary works deal with the topics around human life and experience. These may trigger the students to give response. Through their language they make the students realize how people see and make perception to the world ( what they think, believe and how they feel, enjoy, frighten, even get angry, sad, disappointed etc.). The choice of words, sentence /expression in a certain situation and condition are neutral. The texts are rich with the variety of using language based on context that can not be offered by the text books. All the elements of the text support how to use language perfectly. These phenomenon are really required by the students as a model for interaction during the communication. Culture in language learning is presented within writing, reading, listening and speaking [6]. Therefore in order to teach culture systematically, the teachers should set clear and achievable goals in which the students can develop their intercultural understanding as well as help them with intercultural comunication.

Since literary text can be used to develop the language skills and language components teachers should consider how to select the literary texts. The teacher to take into account needs, motivation, interests, cultural background and the level of the students [7]. Furthermore he mentions that one major factor is the text should be able to arise the learner interest so that it can elicit strong and positive reaction from them. Thus the teaching -learning can be students center. The text even help students develop critical thingking for the literary text generally according to Marley quoted by Khatib deals with universal concepts such as love, hatred, death, nature, etc that are common to all laguages and cultures [8]. Critical thinking is more than thinking logically or analytically: it also means thinking rationally or objectively [5]. Literature can change the attitudes of the learners [5]. Besides, the texts are able to prompt students to question. interprete, connect and explore the meaning.

Literary text can develop the reading skills as it offers the students with vocabulary development in context. The texts lead them to do comprehension and discuss their opinion.The texts trigger them to explore the meaning, getting information they never know before. Thus scanning and skimming skill can be developed. They even learn how to get meaning that implicitly stated in the text. The following quotation are taken from novel Copper Sun (2006) written by Drapper, Sharon.M:

\begin{abstract}
"Amari raised Tidbit's face so he would look around. "She be in every breeze and cloud, every leaf and flower. She smilin' at you right now" Tidbid thought about that. Then he asked her solemnly, "Will you be my mama now Amari?"

She hugged him tightly." Oh yes. Forever I will. You be my little boy, Always".

" Polly be there always too?" “ Always."Amari promised again, even though she knew that keeping promises was sometimes impossible. "Polly be there always too?" He hugged her back, then asked quietly." Is I still a slave, Amari?" Amari looked at the boy with love. "No, Tidbit, You not slave. You free man, just like your mama dream. You never be slave again"

The boy grinned at that. "You be free too Amari?. Amari lookes up at the vast, clear sky and exhaled. "Yes, I be free too. Never, No slave. No more" [9]
\end{abstract}

The two skills of reading, scanning and skimming, as well as comprehension skills can be applied here. Besides there are many questions for the text above can be asked that lead the students to think. The teachers may start from the literal questions to get the answer in detail: such as who are in the story? Who are they? Are they free now? Who is Tibid?. How old is he? Who is Amari ? etc. Then the teachers may move into the inferential questions that lead them to think deeply, and use their critical thinking. The questions such as: Why did Tidbit ask Amari to be her mother?, what happened to his mother do you think?, What does" FREE" mean to them?. What does the meaning "Never, No slave, No More"? How do you feel when you read this? These questions of course depend on the ability of students to react with different answer. Inferential question is better to star from the beginning to make them familiar to think critically. They can work in the group collaboratively to answer the questions and interprete the meaning. Each group can discuss different opinion about the story, characters and condition in which they do not only develop their imagination but also their emotion. The text also can be used for listening comprehesion skill by listening to the tape recorder or watching the video. 
Introduce the vocabulary, breath, solemnly, hugged, grinned, vast, exhaled to students. The are many activities can be done. The teacher may provide them with incomplete sentences where they have to feel the blank with the new words. The teacher then may ask them to make sentences by using the words with their own idea in order to make them familiar with the new words. Using puzzle to introduce new words is also good. Let them understand the expression used in this quotation. These are very interesting since they are simple but can touch the emotion., such as keeping promise was sometimes impossible in life. Amari lookes at the boy with love. They may make their own sentence in the same pattern. Even the expressions such as: You be free too Amari. Is I still a slave. I be free too. can be disscussed in the classroom. Make students realize that the grammar is not correct, why they are wrong and let them put them in a correct grammar. Moreover the material can be used for pronunciation practice based on the context. The story can be developed into speaking and listening skills where the students play the role like in the story or they can create their own dialogue based on the story. The activities such as role play, discussion, deliver speech, debate, etc. The teaching-learning implicitly is integrated. In addition Literature has involved the process of being critically reflexive and working with the knowledge and experiences of the students in the classroom [10]. They learn and experience the life of people culturally, historically, and geographically.

Furthermore, literary works can be a powerful and motivating source for writing EFL both as a model and subject matter [7]. The text can be the model for variety of writing excercises such as guide, control, free and creative writing. Here is the quotation from the novel And the Mountains Echoed written by Khaled Hosseini, that is really touching and show the culture of the certain society.

" Tonight they were going to a party, he, his father, and his little half brother Iqbal. Baitullah had a new infant boy. A motreb would sing for the men, and someone would tap on a tamburine. There would be tea and warm fresly baked bread, and shorwa soup with potatoes. Afterward, Mullah Shekib would dip his finger in a bowl of sweetened water and let the baby suckle it. He would produce his shiny black stone and his doubleedged razor. Lift the cloth from the boy's midriff. An ordinary ritual, life rolling on Sadbagh. Abdullah turned the feather over his hand. I won't have crying. Father had said . No crying, I won't have it. And there had not been any. No one in the village asked after Pari. No one even spoke her name. It astonished Abdullah how thoroughly she had vanished from their lives [11]
The text above does not reflect English culture, but it uses English to tell the story within a certain culture. The sentences are simple and short that promp students to imitate easily. It has arranged in a such way with coherence and cohesion so that it has meaning explicitly and implicitly. The text can be a model for students that writing is not really difficult as what they think. According to Rai (78) the text helps the students gradually improve their skills in writing and organizing their ideas into paragraphs with acceptable sentence sturcture. Therefore the teacher give the model before the students start writing their own. They may start writing from what they know and what they are going to tell. This motivates students to write something that they know or they feel. This is not only a model for narrative but it can trigger students to write different kinds of writing such as recount, descriptive, report even argumentative text depend on their goals. In addition Obediat in Rai (80) states that literary works helps students acquire a native-like competence in English, express their ideas in good English, learn the features of modern English, learn how the English linguistic systems is used for communication, see how idiomatic expressions are used, speak clearly, precisely, and concisely and become ore proficient in English as well as become creative, critical,and analytical learners. In term of culture, the short quotation show the different attitude and treatment of society towards men and women. The man is not allowed to cry. The man, even still a baby get appreciation from society however the woman is nothing for them. Pari, Abdullah's sister has gone but no body pay attention, even asked about her. This case can be an interesting discussion with their own perception that can be related to their own culture. Then they can write how and what the custome in their own culture.

Poem is another genre of Literature that makes the students familiar with figurative language such as irony, metaphor, sarcasm, symbol, imagery, even using idioms. Some people complain that poem tend to use ungrammatical sentence, but that is good for students to find the correct one. Thus before they read they had to put the line in a good grammar. It triggers students to explore the text and have different interpretation. It also can develop the students emotion, and feeling as well as critical thinking. One of stanzas, quoted from poem African Diaspora (1920) written by Chief Charles .O Okereke

Eyes full of the ocean;

Mouth imploded with praises:

Thought stacked full of memories

Memories of motherland Africa

The text above can be a model for students to express their own idea, expression, and feeling in a form of poem. The text is rich with the figurative language that is commonly used by people to express their feeling during the communication. The students are going to understand the way people express their feeling or emotion in interaction. The teacher may star to ask them using figurative language 
in a sentence first. When they are familiar they may start to write a poem, with familiar topic around themselves such as mother, friend, teacher, or a day, a night even moonlight situation, these must be interesting for the yunior or senior school. The important point is to check their ability in grammar. They have learn how to put every lines into the correct grammar, so that they can read and understand what the line means. Besides, the teacher is implicitly triggered to create many activities that make students enthusiastic in learning EFL.

\section{CONCLUSION}

Though literature are simply and imaginative works created by the writer, they are rich with culture, style of language, even situation and condition in which people use a certain expression during an interaction. Therefore they are very useful for materials in teaching English as a Foreign language. The students need to experience using the language they learn to communicate. Literary works as an authentic material offer how the language is used for communication based on the social-cultural context, that may not be fulfilled by the text books. Therefore the teachers are suggested to appliy them in the class,so that they can develop the students skills in intercultural and interlingual communication. The use of sentence, vocabulary, idiom and figurative language in English linguistics system applied by people when they communicate can be found and experienced by the students. The interesting point is the literary text can be used for developing skills of language: Speaking, Reading. Listening and Writing. They even develop critical thinking that involve their mind and emotion. However the teachers should be aware in choosing the text they are going to use in the classroom and be smart how to apply it so that the students can experience the language. Moreover the texts gradually develop their skills in using language as well as their knowledge about the life of human being. The literay texts help them develop their imagination and emotion. Different society, culture, geography and history provide students with the knowledge about the live of people in the world and implicitly build their character to appreciate the difference, as well as their own personality.

\section{References}

[1] Tsai.Yau. Intercultural Communication in IATEFL, VOICE, issue 236. Februari 2014. Oxford University Press. 2014

[2] Kecskes. Istvan. Intercultural Pragmatics.Oxford University Press. New York. 2014

[3] Nickolayev. Vladimir Petrovich, et all. On Subtle Distinctions Between lingual Communication and Interlingual Miscommunication. In Journal of Science and Theology, Agustus 2015,vol 11 no4. 159-168. 2015

[4] Stier. J. Internationalisation, intercultural communication and Interculturar Competence in Journal of Intercultural Communication. Issues 11 2006

[5] Aghagolzadeh, Ferdows and Tajabadi. Farzameh. A Debate on Literature as A Teaching Maaterial in FLT. In Journal of Language Teaching and Research Vol 3.no1 pp 205-210. January 2012. Academy Publisher Manufacture in Findland. 2012

[6] Cruz.J.H.R. The Role of Literature and Culture in English Teaching Forum. 2010

[7] Rai, Asha. Use of Literature in Teaching English. In International Journal of educational Research and Technology. Vol 3. pp. 71-80. 2012 September 2012. India

[8] Khatib,M.Rezaei,S and Derakshan, A. Literature in EFL/ESL classroom. ELT: 201-208. 2011

[9] Drapper. Sharon M. Copper Sun. Simon Pulse. New York. America. 2006

[10] Doecke. Brenton, Mclean Davies, Larissa, Mead, Philip. Teaching Australian Literature: From Classroom Conversations to National Imaginings. Wake Field Press. Kent Town. South Australia. 2011

[11] Hosseini. Khaled. And The Mountains Echoed. New York. America. 2013

[8] Khatib,M.Rezaei,S and Derakshan, A. Literature in EFL/ESL classroom. ELT,4 (1): 201-208. 2011 